\title{
Bioefficacy of plant extracts against fusarium species causing wilt in pulses
}

\author{
Ankita Shukla ${ }^{1}$ and S.K.Dwivedi ${ }^{2}$ \\ ${ }^{1}$ Department of Environmental Science, B.B.Ambedkar University (A Central University), \\ Lucknow -226025, U.P., INDIA \\ ${ }^{2}$ Department of Environmental Science, B.B.Ambedkar University (A Central University), \\ Lucknow-226025, U.P., INDIA
}

\begin{abstract}
In vitro efficacy of different plant extracts viz. Bitter guard, Turmeric, Garlic and Black pepper has been tested to control both fusarial species viz. fusarium udum (causing wilt in pigeonpea) and fusarium oxysporum f.sp.ciceri (causing wilt in chickpea). Both pathogenic fungi have been isolated from infected plant parts and identified on the basis of their morphological and cultural characteristics. Different concentration i.e. 5\%, $10 \%$ and $15 \%$ of plant extracts are taken in the swot. All the plant extracts showed considerable diminution in the growth of pathogens. Growth of fusarium udum has been reduced by $15 \%$ concentration of turmeric $(\mathbf{8 9 . 2 \%})$ followed by garlic $(\mathbf{8 8 . 2 6 \%})$ and black pepper $(\mathbf{8 2 . 2 2 \%})$. In case of fusarium oxysporum f.sp.ciceri, $15 \%$ concentration of garlic, turmeric and black pepper reduced the growth upto $94.63 \%, 87.96 \%$ and $77.74 \%$ (at $p<0.01$ ) respectively. From the above observations it can be postulated that growth of both the pathogens has been significantly reduced (at $p<0.01)$ by garlic and turmeric extracts followed by extract of black pepper. The bitter guard extract is found least effective against both the pathogens at all concentrations. In addition to this $10 \%$ concentration of garlic and turmeric is also found effective against both the pathogens.
\end{abstract}

Keywords: growth, non-pollutive, pathogens, plant extracts.

\section{INTRODUCTION}

From past many years a number of different chemical and synthetic compounds have been used against phytopathogens. Indiscriminate use of these chemicals has led to development of fungicide resistance $[1,2]$ and more importantly, environmental pollution, posing a potential risk to animal and human health [3]. Due to high cost and hazardous effect of used chemical pesticides from last thirty years, fresh plant extracts from plant parts became valuable to control pathogens $[4,5]$. To control the pathogens, plant extracts have been used as antifungal agents. These extracts can be easily prepared by farmers [6].

The presence of antifungal compound is an important factor for disease control in higher plants [7]. These compounds are biodegradable and toxic to a considerable value for suppressing some plant diseases [8]. The pre harvest losses due to fungal diseases in world crop protection may reach up to $12 \%$ or even higher in developing countries $[9,10]$. Modern agrochemical research influence the application of plant derived fungicides and it has enormous potential against microbial pathogens attack due to presence of secondary metabolites in plants [11].

The bioactivity of neem extracts has been attributed by various compounds such as nimbin, nimbidin and salannin and most important antifungal compound is azadirachtin [12]. Bitter cucumber contains an array of biologically active plant chemicals including triterpenes, proteins and steroids. The main compound in kaffir lime leaves is citronellal (65.4\%) whereas the major constituents in essential oil of kaffir lime seeds are $\beta$-pinene (30.6\%), limonene (29.2) and sabinene (22.6\%) [13]. The inhibitory effect of fungal growth by kaffir lime leaf might be due to citronellal. The antifungal activity of garlic has been demonstrated by various agencies [14, 15]. Plant extracts prepared with cold water has strong antifungal activity with effective inhibition potential against pathogen.

The major setback in the control of Fusarium udum and fusarium oxysporum f.sp.ciceri in the study area has been low per capita income; with household poverty incidence among subsistence farmers, even though it is classified as high potential zone in terms of Agricultural productivity. This situation has hindered small-scale subsistence farmers acquiring synthetic chemicals to control fungal infection of pigeonpea and chickpea. This scenario, therefore, calls for alternative approaches to control of soil borne pathogens. The approach needs to be economically feasible and eco-friendly to increase yield of pigeonpea and chickpea. This study focused at evaluating the phytotoxic activity of locally available four extracts of bitter guard, turmeric, garlic and black pepper against radial growth of Fusarium udum and Fusarium oxysporum f. sp. ciceri. 


\section{Ankita Shukla and S.K.Dwivedi / IOSR Journal of Engineering (IOSRJEN) \\ www.iosrjen.org ISSN : 2250-3021}

Vol. 2 Issue 1, Jan.2012, pp. 136-144

\section{MATERIAL AND METHOD}

Soil samples and plant parts showing wilt characteristic has been collected from the field of pigeonpea and chickpea. The samples have been taken from Kalli paschim village, District Sarojini nagar, Lucknow in September, 2009. The plant parts are examined under microscope to confirm the presence of respective pathogen. First of all infected plant parts are cut into pieces $(2-3 \mathrm{~mm})$, then it is surface sterilized with $0.1 \%$ mercuric chloride solution for 30 seconds. The isolation has been made from roots as well as from the foliar parts of wilted pigeonpea and chickpea plants. The plant parts are washed three times with sterilized distilled water and transferred aseptically on Potato Dextrose Agar (PDA) media. The inoculated plates has been incubated at room temperature $\left(27 \pm 2^{\circ} \mathrm{C}\right)$ and observations are made daily for emergence of culture. After the development of the fungal colonies stock cultures have been prepared using PDA in test tubes and stored in refrigerator at $4^{\circ} \mathrm{C}$. Both wilt pathogens are isolated from infected pigeonpea and chickpea plants and identified as per the monograph and standard procedures.

A 50\% w/v stock solution of Turmeric (Curcuma longa) (Family Zingiberaceae ), Black pepper (Piper nigrum) (Family Piperaceae), Garlic ( Allium sativum) (Family Liliaceae) and Bitter guard (Mimordica charantia) (Family Mimodaceae) has been prepared in sterilized water and then passing it through muslin cloth and finally filtered through whatman filter paper. Different concentration i.e. $10 \%, 20 \%$ and $30 \% \mathrm{w} / \mathrm{v}$ are prepared by adding quantity of sterile water into the stock solution. The stock solution is heated up to $40-50^{\circ} \mathrm{C}$ for 10 minutes to avoid contamination. To evade contamination and chemical alteration, the extract has also been stored at $4^{\circ} \mathrm{C}$ [16].

\subsection{In vitro study}

The activity of all four plants extract is tested against both the pathogen by poisoned food technique [17]. The 10, 20 and $30 \%$ conc. of plant extracts are mixed separately in 90ml. sterilized czapek-dox agar medium and poured into petriplates. In control plates, sterilized distilled water is added with czapek-dox agar medium in place of plant extract. Each treatment replicates three times. After solidification of the medium, 5mm. diameter plug from 7 days old colony of fusarium udum and fusarium oxysporum f.sp. ciceri is inoculated separately in the center of each petriplates and incubated at $25 \pm 2^{\circ} \mathrm{C}$. The colony diameter of both the pathogens has been measured after 7 days of incubation.

\section{RESULTS AND DISCUSSION}

It is found from experiment that bitter guard extract inhibits the growth of fusarium udum up to $34.74 \%, 61.30 \%$ and $67.15 \%$ at $5 \%, 10 \%$ and $15 \%$ concentration respectively and $\mathrm{R}^{2}$ value is found to be 0.880 (Figure $1 \mathrm{a}$ ). The growth of fusarium udum has been reduced to $78.52 \%$ at $5 \%$ concentration, $82.22 \%$ at $10 \%$ concentration and $89.22 \%$ at $15 \%$ concentration with extract of turmeric while $\mathrm{R}^{2}$ value is obtained 0.981 (Figure $1 \mathrm{~b}$ ). In case of garlic extract, the percentage reduction in growth has been found to be $76.67 \%, 83.04 \%$ and $88.26 \%$ at $5 \%, 10 \%$ and $15 \%$ concentration accordingly (Figure 1c). $\mathrm{R}^{2}$ value for these concentrations of garlic is found 0.996 . Similarly black pepper reduced the growth of fusarium udum up to $65.19 \%$ at $5 \%$ concentration, $72.19 \%$ at $10 \%$ concentration and $82.22 \%$ at $15 \%$ concentration respectively and $\mathrm{R}^{2}$ value has been found 0.989 (Figure 1d).

In case of fusarium oxysporum f.sp.ciceri growth of pathogen has been reduced by $61.70 \%$ at $5 \%, 66.11 \%$ at $10 \%$ and $69.26 \%$ at $15 \%$ concentration with extract of bittergourd with $\mathrm{R}^{2}$ value of 0.99 (Figure $2 \mathrm{a}$ ). On the other hand, with turmeric extract, the growth reduction is found $74.96 \%, 85.04 \%$ and $87.96 \%$ at $5 \%$, $10 \%$ and $15 \%$ concentration respectively with $\mathrm{R}^{2}$ value of 0.908 (Figure $2 \mathrm{~b}$ ) followed by reduction of $73.07 \%$ at $5 \%$, $89.70 \%$ at $10 \%$ and $94.63 \%$ at $15 \%$ concentration with extract of garlic. Here the $\mathrm{R}^{2}$ is found 0.910 (Figure $2 \mathrm{c}$ ). Similarly black pepper reduced the growth up to $62.22 \%$ at $5 \%, 71.41 \%$ at $10 \%$ and $77.74 \%$ at $15 \%$ concentration with extract of Black pepper (Figure $2 \mathrm{~d}$ ). $\mathrm{R}^{2}$ value for these concentrations of black pepper is obtained 0.98 . 
Ankita Shukla and S.K.Dwivedi / IOSR Journal of Engineering (IOSRJEN) www.iosrjen.org

Vol. 2 Issue 1, Jan.2012, pp. 136-144

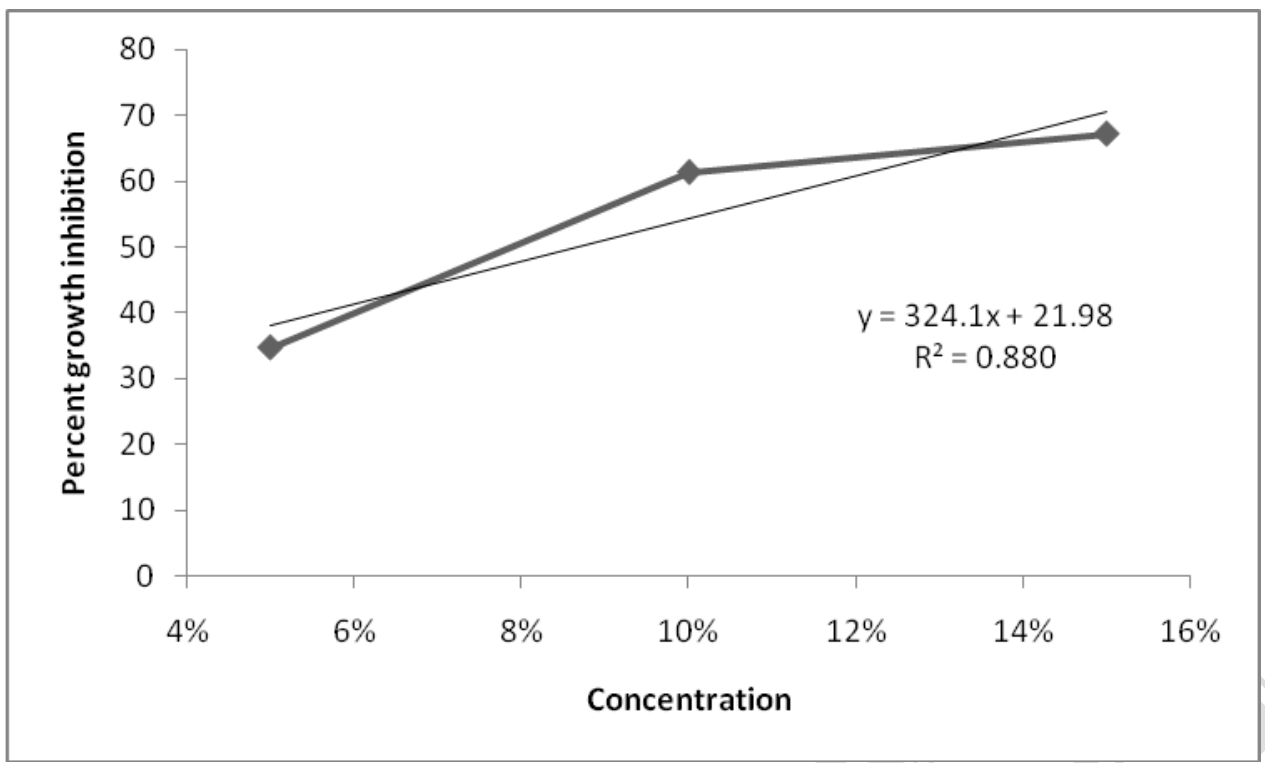

Fig. 1(a) Effect of different concentration of Bitter guard on growth of Fusarium udum Significant at $\mathbf{p}<\mathbf{0 . 0 1}$ level according to Duncan's multiple Range test.

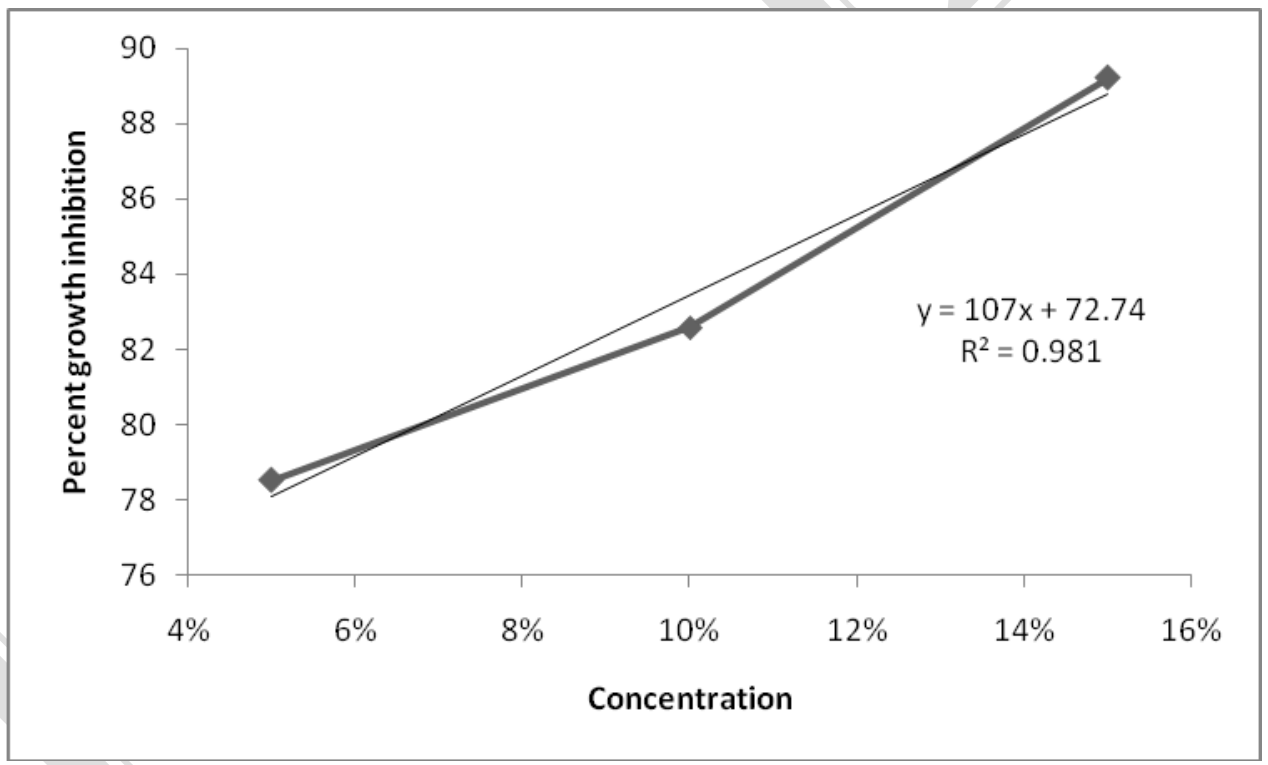

Fig. 1(b) Effect of different concentration of Turmeric on growth of Fusarium udum Significant at $\mathbf{p}<0.01$ level according to Duncan's multiple Range test. 
Ankita Shukla and S.K.Dwivedi / IOSR Journal of Engineering (IOSRJEN) www.iosrjen.org

Vol. 2 Issue 1, Jan.2012, pp. 136-144

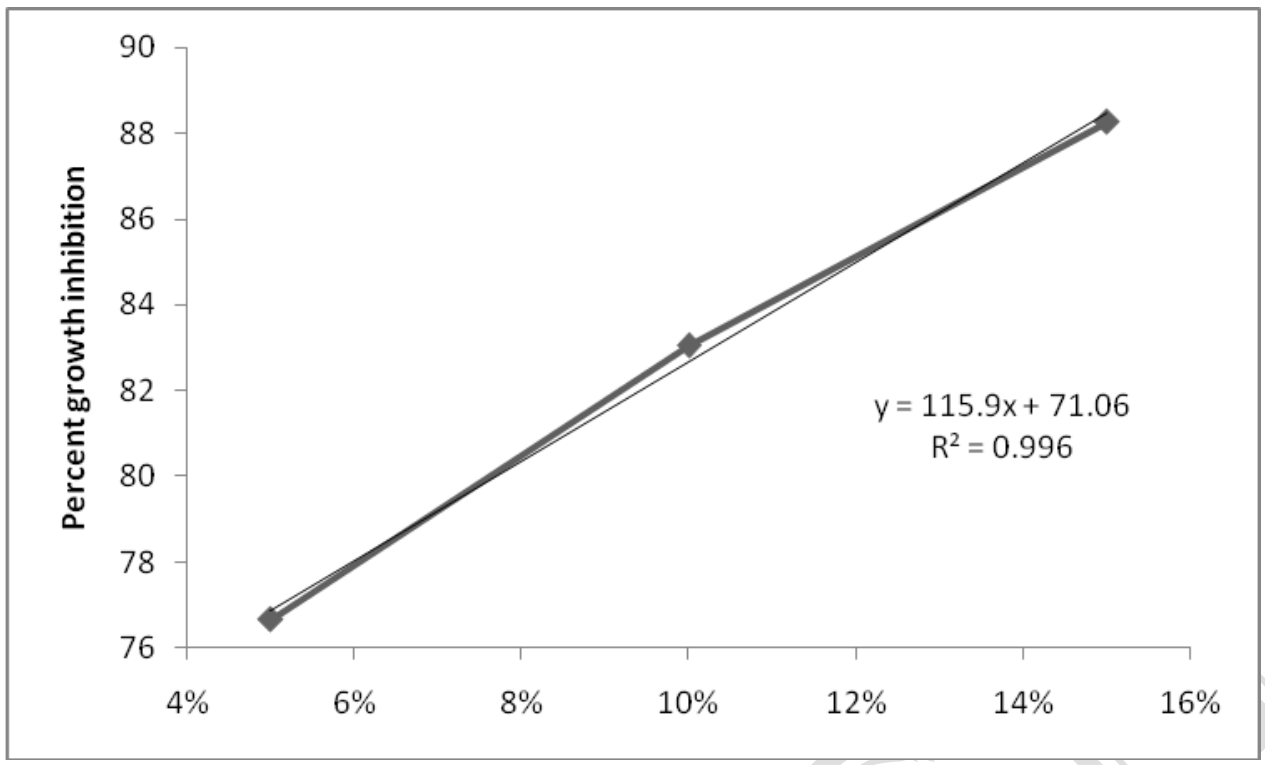

Fig. 1(c) Effect of different concentration of Garlic on growth of Fusarium udum Significant at $\mathbf{p}<0.01$ level according to Duncan's multiple Range test.

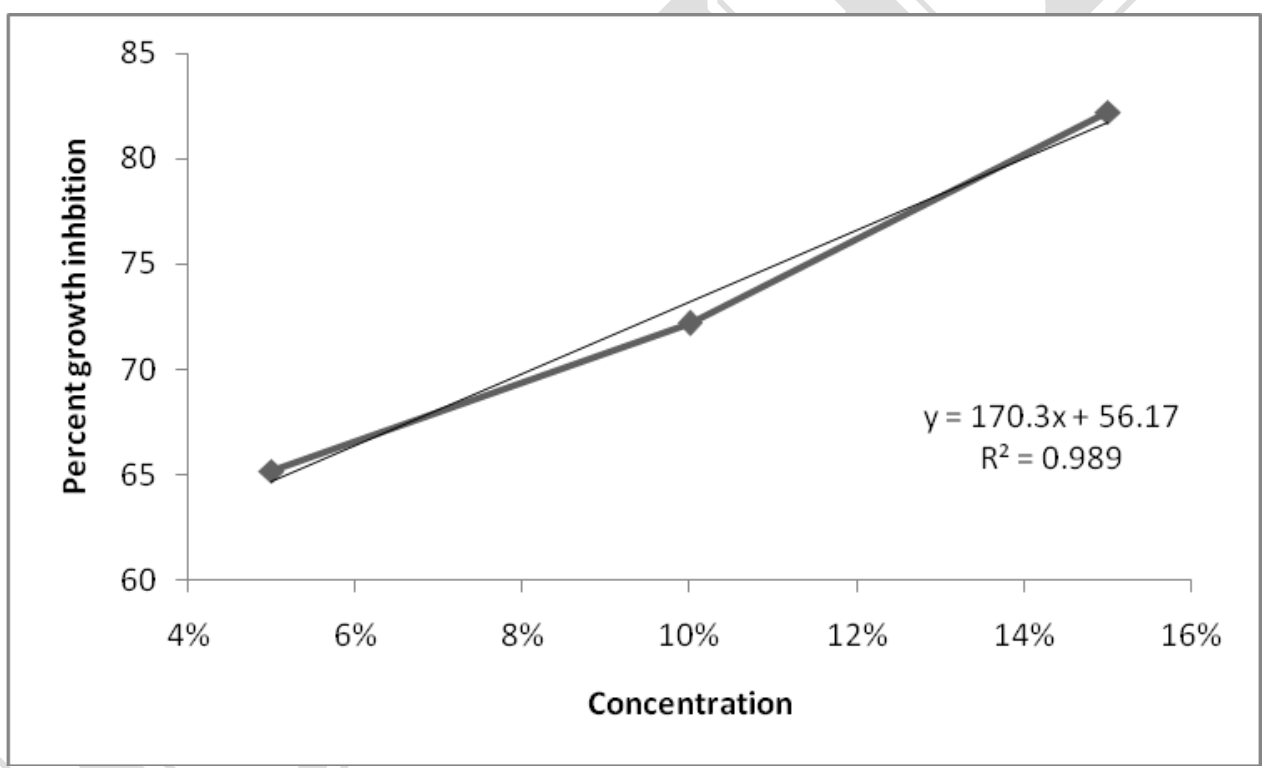

Fig. 1(d) Effect of different concentration of Black pepper on growth of Fusarium udum Significant at $\mathbf{p}<0.01$ level according to Duncan's multiple Range test. 
Ankita Shukla and S.K.Dwivedi / IOSR Journal of Engineering (IOSRJEN) www.iosrjen.org

Vol. 2 Issue 1, Jan.2012, pp. 136-144

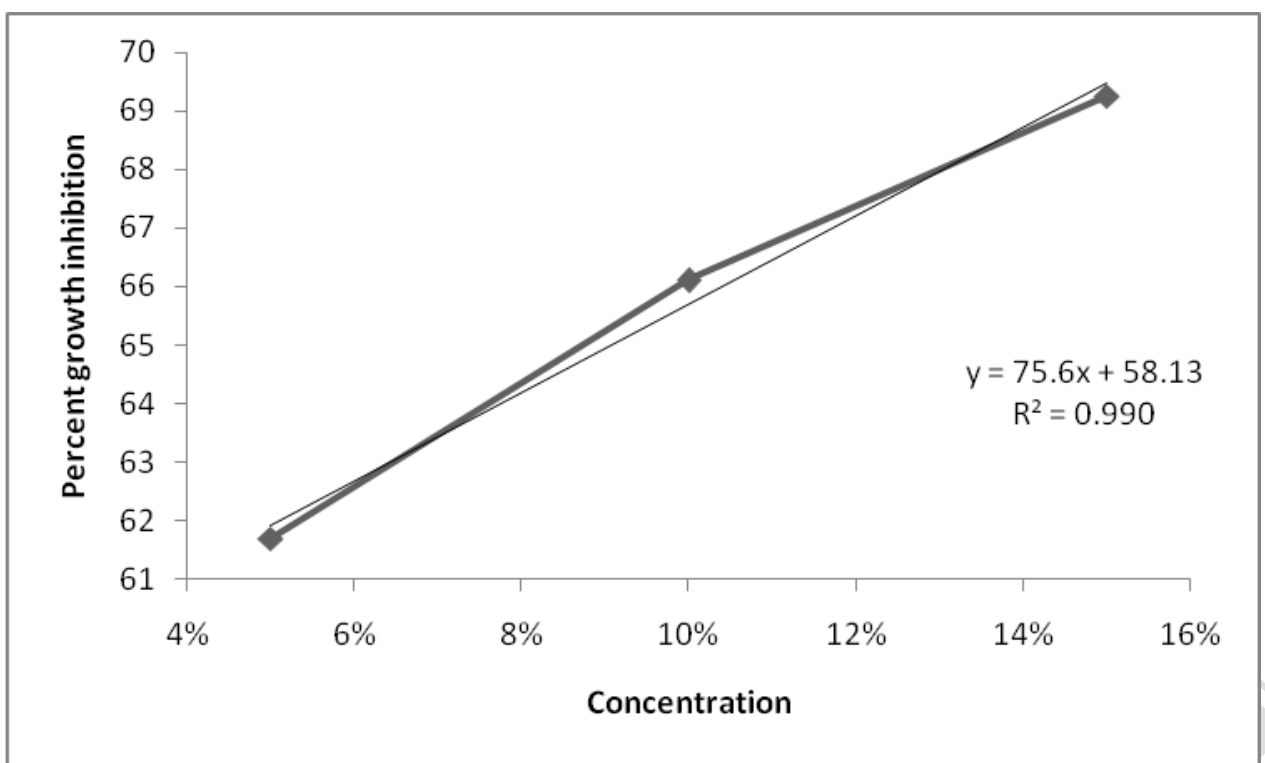

Fig. 2(a) Effect of different concentration of Bitter guard on growth of Fusarium oxysporum f.sp.ciceri Significant at $\mathbf{p}<0.01$ level according to Duncan's multiple Range test.

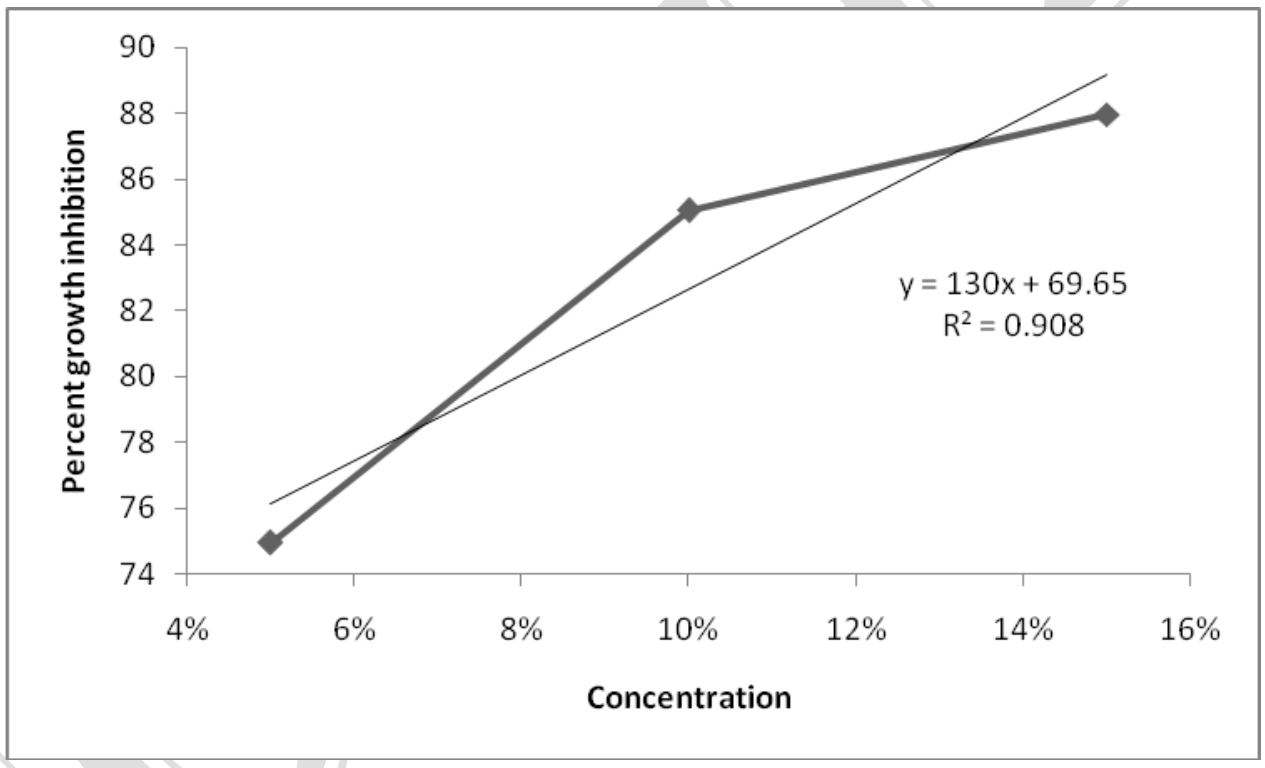

Fig. 2(b): Effect of different concentration of Turmeric on growth of Fusarium oxysporum f.sp.ciceri Significant at $\mathbf{p}<0.01$ level according to Duncan's multiple Range test. 
Ankita Shukla and S.K.Dwivedi / IOSR Journal of Engineering (IOSRJEN)

www.iosrjen.org

ISSN : 2250-3021

Vol. 2 Issue 1, Jan.2012, pp. 136-144

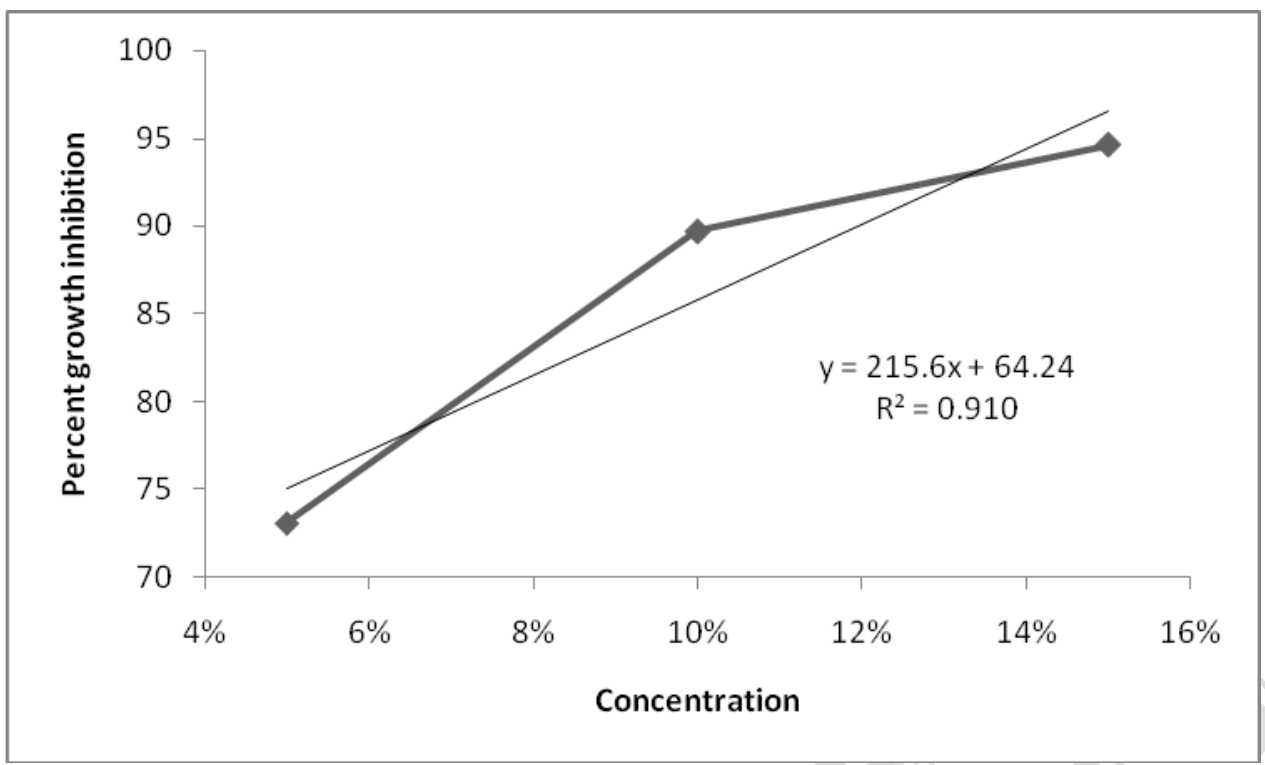

Fig. 2(c): Effect of different concentration of Garlic on growth of Fusarium oxysporum f.sp.ciceri Significant at $\mathbf{p}<0.01$ level according to Duncan's multiple Range test.

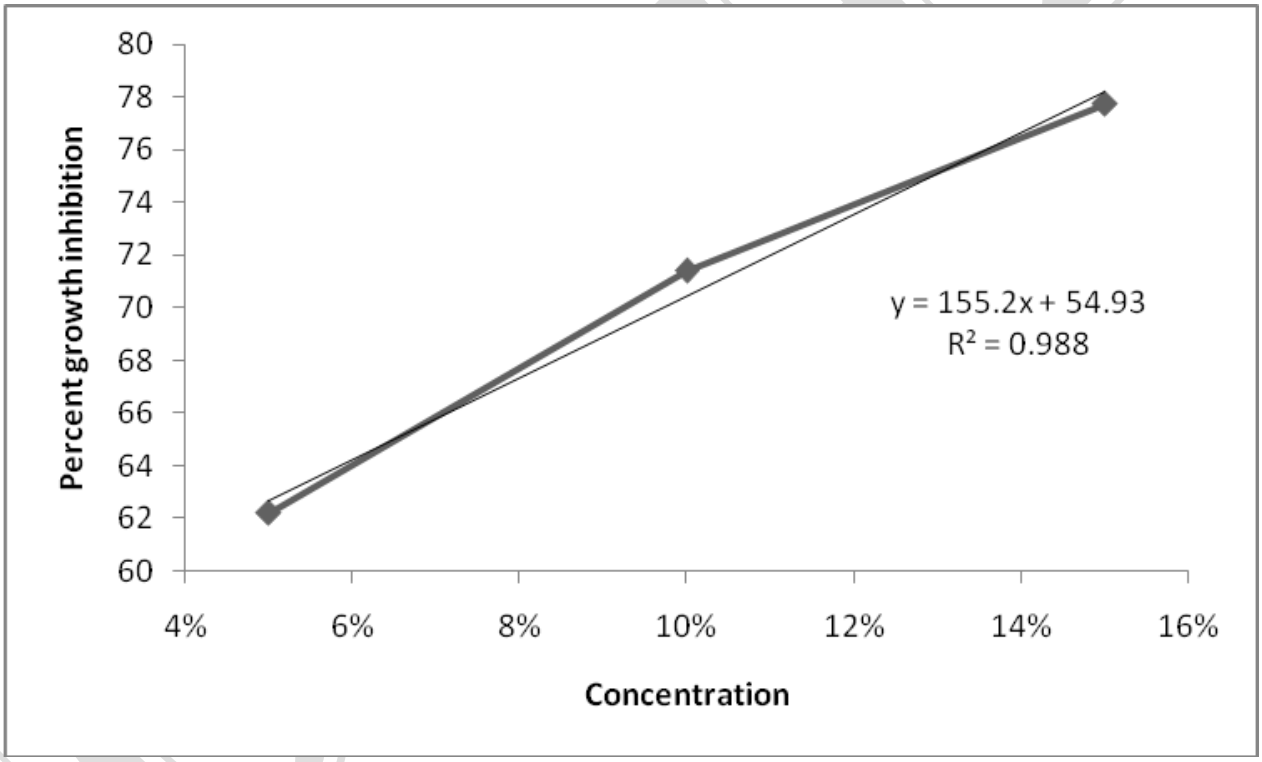

Fig. 2(d): Effect of different concentration of Black pepper on growth of Fusarium oxysporum f.sp.ciceri Significant at $\mathbf{p}<0.01$ level according to Duncan's multiple Range test.

From the experimental analysis, it is found that growth of both the pathogens has been significantly ( $>0.01$ ) reduced primarily by garlic and turmeric extracts followed by black pepper extract. The extract of bitter guard is found least effective against both the pathogens.

Uzma et al. (2008) tested antifungal activity of asafetida (Ferula asafoetida), black cumin seed (Nigella sativa), neem (Azadirchta indica) and mustard (Brassica compestris) oils against eight fungal species viz. Aspergillus flavus, Aspergillus niger, Fusarium moniliformae, Fusarium oxysporum, Fusarium nivale, Fusarium semitectum, Alternaria alternate and Drechslera hawiensis [18]. Bowers and Locke (2000) found that $10 \%$ aqueous emulsion of pepper, clove and cassia extracts reduced the growth of fusarium oxysporum f.sp.chrysanthemi (Foc) in soil by $99.9 \%, 97.5 \%$ and $96.1 \%$ after three days of incubation, while 5\% aqueous emulsion of pepper extracts reduced the population densities of Foc by $99.9 \%$ [19]. 


\section{Ankita Shukla and S.K.Dwivedi / IOSR Journal of Engineering (IOSRJEN) \\ www.iosrjen.org ISSN : 2250-3021 \\ Vol. 2 Issue 1, Jan.2012, pp. 136-144}

During their study Hassanein et al. (2008) observed that 5\%, 10\%, 15\% and 20\% concentration of neem extract effectively suppressed the mycelial growth of both species Alternaria solani (causing early blight) and Fusarium oxysporum f.sp. lycopersici (causing wilt disease) in tomato. $20 \%$ concentration of ethanol and ethyl acetate extracts of neem totally inhibited the growth of Alternaria solani at $52.44 \%$ to $62.77 \%$ [20].

Fusarium oxysporum f.sp.ciceri, Rhizactonia solani, Sclerotium rolfsii and Sclerotinia sclerotium causing wilt and rot in Cicer arietinum controlled by leaf trunk and oil extracted from neem tree [21]. Different extracts from neem leaves were found to have inhibitory action against Trichoderma viridae, Fusarium oxysporum and Pythium apanideratum [22].

The mycelial growth inhibition rate increased with increasing plant extract concentration. At $100 \%$ aqueous neem leaf extract caused complete inhibition of spore germination of Fusarium spp. [23]. Babu joseph [24] tested different concentration i.e. 5\%,10\%, 15\% and 20\% extract of different plants viz., Artemessia annua, Eucalyptus globulus, Ocimum sanctum and Rheum emodi and found significant reduction in growth of fusarium solani f. sp. melongenae. Azadirchta indica was found most effective at $20 \%$ concentration followed by Rheum emodi, Eucalyptus globulus, Artemessia annua and Ocimum sanctum.

Kalpana Bhatnagar [25] tested 17 plant species against fusarium oxysporum f.sp.cumini and found that datura and isabgul extract showed maximum inhibition. Neem, garlic and turmeric plant extract showed moderate effect. Garlic extract caused maximum inhibition of fusarium moniliformae [26].

The ethanolic extracts of kaffir lime leaves inhibited some strains of salmonella [27]. Crude ethanolic extracts of $10 \%$ concentration of kaffir lime leaf, $8-10 \%$ concentration of tobacco leaf and $6 \%, 8 \%$ and $10 \%$ concentration of bitter cucumber fruit effectively suppress the growth of Aspergillus flavus [28] . 5 and $10 \mathrm{~g} / 100 \mathrm{ml}$. conc. of kaffir lime inhibit the spore germination of fungal species viz., Colletotrichum gloeosporioides and Fusarium sp. respectively [29].

Khalil [30] tested different concentrations i.e. $0.5 \%, 1 \%$ and $2 \%$ concentration of Garlic, Craway, Carnation, Half-bar, Neem and different antagonists viz,. Trichoderma harrzianum and Trichoderma viride and one fungicide Benomyl against Fusarium oxysporum f.sp.lycopersici. Result showed that Garlic and craway effectively inhibited the growth of pathogen followed by Carnation, Half-bar and Neem. The cultural filtrate of the antagonists fungus $T$. harzianum was found to be more effective than T.viride to decreased the growth of fungal species but less than benomyl.

Neem extract inhibited the germination of Fusarium moniliformae in sorghum as reported by Rai [31]. The crude boiled and acetone extract of Allium sativum caused 100\% inhibition of the mycelial growth of Rhizactonia solani [32].

Azadirchta indica and Datura metel plant extract showed higher fungitoxicity against Fusarium oxysporum f.sp.ciceri [16]. Chandra and Singh [33] described that plant extract of Calotropis procera, Eucalyptus globulens, Jatropha multifida, Azadirchta indica, Allium sativum significantly reduced the wilt incidence in Cicer arietinum. Mycelial growth of various fusarium species were inhibited by plant extracts of Adhatoda vasica, Azadirachta indica, Cinnamomum camphora and Ocimum sanctum [34]; Agave Americana, Cassia nodosa [35] ; Azadirchta indica [36] ; Azadirchta indica, Atropha belladonna, Calatropis procera, Eucalyptus amygdalina, Ailanthus excelsa and Lantana camera [37].

\section{CONCLUSION}

It is concluded from above results that Turmeric significantly checked the growth of Fusarium udum by $89.22 \%$ followed by Garlic (88.26\%), Black pepper $(82.22 \%)$ and Bitter gourd $(67.15 \%)$ at $15 \%$ concentration (at $\mathrm{p}<0.01)$ respectively, whereas in case of Fusarium oxysporum $f$. sp. ciceri , 94.63\%,87.96\%, 77.74\% and $69.26 \%$ reduction in growth at $15 \%$ concentration with garlic, turmeric, black pepper and Bitter gourd extract has been recorded (at $\mathrm{p}<0.01$ ). Among plant extracts higher concentration of turmeric, garlic and black pepper effectively reduced the growth of Fusarium udum and Fusarium oxysporum.f.sp.ciceri. Turmeric, garlic and black pepper can be used in reducing the wilt incidence in pigeonpea and chickpea. From present study it is postulated that plant extract can be used as a viable option for natural pesticides. 


\section{Ankita Shukla and S.K.Dwivedi / IOSR Journal of Engineering (IOSRJEN) \\ www.iosrjen.org ISSN : 2250-3021}

Vol. 2 Issue 1, Jan.2012, pp. 136-144

\section{REFERENCES}

[1] R.N.Okigbo, A review of biological control methods for post harvest yams Dioscorea spp.) in storage in South Eastern Nigeria, KMITL Sci J. ,4(1), 2004, 207 - 215.

[2] G.A. Carvalho, Filtered effect in vitro and in alive of of Gloeosporioides rizobacteria on Colletotrichum penz. of the coffee tree, 55 Dissertação (Mestrado in Agronomy) - Federal University of YOU cultivate, You cultivate, 2004.

[3] Lyon, G.D., Beglinski, T. and Newton, A.C. 1995. Novel disease control compounds: the potential to 'immunise' plants against infection. Plant Pathology 44:407-427.

[4] M. Grainge and S. Ahmad, Handbook of plants with pest control properties. John Wiley and Sons.,New York, 1988 .

[5] A.B.K. Jespers and M.A.Wards, Natural products in plant protection, Netherland J.Plant Pathol.99(3), 1993,109-117.

[6] R.N.Okigbo and I.A. Nameka, Control of yam tuber with leaf extracts of Xylopia aethiopica and Zingiber officinale, Afr. J. Biotechnol.4(8), 2005, $804-807$.

[7] A. Mahadevan, Biochemical aspects of plant diseases resistance. Part 1. Preferred inhibitory substance prohibition, Today and Tomorrow Printer and Publisher,New Delhi, 1982.

[8] R.K. Singh and R.S. Dwivedi, Effects of oils on Sclerotium rolfsii causing root-rot to barley. Indian Phytopathology, 40, 1987,531-533.

[9] E.C.Oreke, H.C.Dehne, F.Schonbeck and A.Weber, Crop production and crop protection: Estimated loss in major food and crash crops, 1994, Elsevier,Amesterdam.

[10] G.N. Agrios, Plant Pathology, The 4th edition. Academic Press, San Diego, 1997.

[11] J.P. Benner, Pesticidal compounds from higher plants, Pesticide Sci., 39, 1993, 95-102.

[12] N.E.S. Lale and H.T. Abdulrahman, Evaluation of neem (Azadirchta indica A. Juss) seed oil obtained by different methods and neem powder for the management of Callosobruchus maculates(F.) (Coeloptera: Burchidae) in stored cowpea, J.Stored Peod. Res., 35, 1999,135-143.

[13] B.M. Lawrence, J.W. Hogg, S.T. Tehune and V. Podimuang, The leaf and peel oils of Citrus hystrix, 1970, D.C.Bangkok,ASRCT.

[14] Research Council Board of Agriculture, Regulating pesticides in Food. The Delaney Paradox. National Academy Press. Washington,D.C., 1987.

[15] C.L. Wilson, J.M. Solar, A.E.Ghaouth and M.E. Wisniewski, Rapid evaluation of plant extracts and essential oils for antifungal activity against Botrytis cinerea, Plant Disease, 81, 1997,204-210.

[16] Irum Mukhtar, Comparison of phytochemical and chemical control of Fusarium oxysporum f.sp.ciceri. Mycopath., 5(2), 2007,107-110.

[17] Y.L. Nene and P.N. Thapliyal, Fungicides in plant disease control, Oxford \& IHB Publ. Co.,New Delhi, $1979,507$.

[18] Uzma Sitara, Ishrat Niaz, Jawed Nassem and Nasreen Sultana, Antifungal effect of essential oils on in vitro growth of pathogenic fungi, Pak. J. Bot., 40(1), 2008,409-414.

[19] J.H. Bowers and J.C. Locke, Effects of botanical extacts on the population density of Fusarium oxysporum in soil and control of Fusarium wilt in the greenhouse, Plant Disease, 84, 2000,300-305.

[20] N.M. Hassanein, M.A. Abou Zeid, K.A. Youssef and D.A.Mahmoud, Efficacy of leaf extracts of Neem (Azadirachta indica) and Chinberry (Melia azedrach) against early blight and wilt disease of tomato, Australian Journal of Basic and Applied Sciences, 21(3), 2008,763-772.

[21] Rajesh Singh, B.K.Singh, R.S.Upadhyay, Bharat Raj and Youn see Lee, Biological control of Fusarium wilt disease of pigeonpea, Plant pathology J. ,18(5), 2002, 279-283.

[22] B.K.Sharma,Antifungal properties of biocontrol agents and plant extract against causal fungi of yellow and rhizome rot of ginger, J. of Biol. Control, 12(1), 1998, 77-80.

[23] B.P. Dwivedi and D.N. Shukla, Effect of leaf extracts of some medicinal plants on spore germination of some Fusarium sp. Karnataka J. of Agri. Sci., 13(1), 2000, 153-154.

[24] B. Joseph, Dar, M. Ahmad and V. Kumar ,Bioefficacy of plant extracts to control Fusarim solani f.sp.melanogenae incitant of brinjal wilt, Global J.of Biotechnology and Biochemistry, 3(2), 2008, 56-59.

[25] K.Bhatnagar, B.S.Sharma and H.S.Cheema, Efficacy of plant extracts against Fusarium oxysporum f.sp.cumini causing wilt in cumin, J. Mycol. Pl. Pathol., 34(2), 2004,360-361.

[26] V.P. Gohil and D.G. Vala, Effect of extracts of some medicinal plants on the growth of Fusarium moniliformae, J. Mycol.Pl. Pathol.,26, 1996. 110.

[27] S. Nanasombat and P. Lohasupthawee, Antibacterial activity of crude ethanolic extracts and essential oils of spices against Samonellae and entrobacteria,KMITL, Science and Technology Journal,5(3), 2005, 527538. 


\section{Ankita Shukla and S.K.Dwivedi / IOSR Journal of Engineering (IOSRJEN) \\ www.iosrjen.org \\ ISSN : 2250-3021}

\section{Vol. 2 Issue 1, Jan.2012, pp. 136-144}

[28] T. Dusanee, C. Sittichai, P. Kanokwan and U. Kittipun, Inhibitory effect of kaffir lime, bitter cucumber and tobacco extracts on the growth of Aspergillus flavus. KMITL Sci. Tech. J.,6(1), 2006,18-24.

[29] K. Noengpa , P. Prayoonrat and S.Chingduang, Efficiency of certain medicinal plants to inhibit Colletrotrichum gloeosporioidesi and fusarium sp., http://plantpro doae.go.th/., 2006.

[30] Mastry EL-MH Khalil Al, M.S. Hassouna and H.A.H. Ibrahim, In situ and in vitro suppressive effect of agricultural composts and their water extracts on some phytopathogenic fungi, World journal of Microbilogy and Biotechnology, 18 , 2002, 551-558.

[31] V.R.Rai ,S.Lokesh and K. Ayub, Occurrence and management of somre seed-borne fungal pathogens of maize and sorghum in vitro. Seed Res.,30, 2002,112-117.

[32] P. Kane, A. Jadhav Kshirsagar and N. Pawar, In vitro evaluation of some plant extracts against Rhizactonia solani from chickpea, J. Maharastra Agric. Univ.,27, 2002,101-102.

[33] H. Chandra and S. Singh, Control of chickpea wilt(Fusarium oxysporum f.sp.ciceri) using bioagents and plant extracts. Indian J. Agric. Sci.,75(2), 2005,115-116.

[34] A.K.Prasad and N.L.Ojha, Antifungal evaluation of leaf extracts for the control of some cucurbitaceous fruit rot diseases, Indian Phytopathology ,39, 1986,153.

[35] V.K.Reddy and S.M.Reddy, Screening of indigenous plants for their antifungal principal, Pesticides, 21, 1987,17-18.

[36] S. Eswaramoorthy, S. Muthuswamy and V. Mariappan, Neem.Newsletter, 6(1), 1989, 4-5.

[37] K.R. Bansal and K.G. Rajesh, Evaluation of plant extracts against Fusarium oxysporum, wilt pathogen of fenugreek, Indian J. Phytopathology, 53(1), 2000, 107-108. 